Jurnal Penelitian Humano, Vol. 9 No. 2 Edisi November 2018

\title{
Pengaruh Media Sosial (Facebook) Terhadap Pola Kebahasaan Mahasiswa Fakultas Ilmu Budaya Universitas Khairun
}

\section{Ikmal Muhamad}

\author{
Pengajar Fakultas Ilmu Budaya,Universitas Khairun \\ Email : $\underline{\text { ikmalmuh.fib@gmail.com }}$
}

\begin{abstract}
Abstrak. Facebook merupakan jejaring sosial yang terdiri dari elemen-elemen individual atau organisasi. Jejaring ini menunjukan jalan dimana mereka berhubungan karena kesamaan sosialitas, mulai dari mereka yang dikenal sehari-hari sampai dengan keluargaRuang halusinatif (Cyberspace pada satu titik dimaknai sebagai ruang halusinatif yang dibentuk melalui media digital berupa bit-bit) informasi dalam database komputer, yang akan menghasilkan pengalaman-pengalaman halusinatif yang hidup di sekeliling kabel telepon, kabelfiber-optik dan gelombang elektromagnetik ini dihuni oleh berbagai macam pengetahuan,pada dasarnya ini telah menjadi sebuah dunia optik yang menjadi alternatif bagi dunia nyata tempat kita hidup. Dengan fungsinya sebagai media komunikasi, Facebook tentu juga bertanggungjawab pada perubahan pola perilaku subjek yang menggunakannya, dan salah satunya dari segi kebahasaan.
\end{abstract}

Kata Kunci : Media sosial, bahasa

Abstract. Facebook is a social network consisting of individual elements or organizations. This network shows the way in which they are related because of the similarity of sociality, starting from those known everyday to family. Hallucinative space (Cyberspace at one point is interpreted as hallucinatory space formed through digital media in the form of bits) information in a computer database producing hallucinatory experiences that live around telephone cables, fiber-optic cables and electromagnetic waves inhabited by various kinds of knowledge, basically this has become an optical world that becomes an alternative to the real world in which we live. With its function as a communication medium, Facebook is of course also responsible for changing the behavior patterns of the subjects who use it, and one of them is in terms of language.

Keywords: Social media, language

\section{PENDAHULUAN}

Internet telah menjadi teknologi yang paling penting bagi seluruh umat manusia di abad ini. Hampir setiap orang kini telah mengerti atau mahir menggunakan internet. Sebagai bagian dari perangkat informasi dan komunikasi, fitur yang paling populer di 
Jurnal Penelitian Humano, Vol. 9 No. 2 Edisi November 2018

internet adalah Sosial Media, Facebook adalah salah satunya.

Jejaring sosial pertemanan ini tidak hanya menghubungkan individu, tetapi juga kebudayaan secara universal. Dengan jumlah pengguna sebanyak 1,44 Milyar pada kuartal kedua tahun 2015, Facebook adalah media sosial dengan jumlah pengguna terbanyak diantara media-media sosial lainnya di seluruh dunia. Dari jumlah tersebut, 70 juta pengguna berasal dari negara Indonesia.

Dengan fungsinya sebagai media komunikasi, Facebook tentu juga bertanggungjawab pada perubahan pola perilaku subjek yang menggunakannya, dan salah satunya dari segi kebahasaan. Hal ini tidak terlepas dari sifat bahasa yang arbitrer dan dinamis, yang berarti bahwa bahasa selalu dapat berubah mengikuti jaman. Bahasa sebagai alat komunikasi berkembang mengikuti perkembangan yang terjadi pada lingkungan penuturnnya. Berbagai kata baru masuk entri kamus setiap tahun sebagai pembaharuan suatu bahasa. Banyak orang berpendapat bahwa perkembangan internet dan media sosial akan berpengaruh terhadap perkembangan suatu bahasa, baik itu pengaruh buruk ataupun pengaruh baik.
Prospek dari pengaruh dalam aspek kebahasaan oleh media sosial Facebook tidak terkecuali juga terjadi pada mahasiswa di Fakultas Sastra dan Budaya - Universitas Khairun, kemudahan akses dan mobilitas penggunaannya dalam berkomunikasi antarpersonal menjadikan Facebook sebagai jejaring sosial yang berpotensi mengubah penggunaan bahasa tulisan maupun lisan dalam interaksi mahasiswa Fakultas Sastra dan Budaya - Universitas Khairun seharihari, baik di kampus maupun di rumah. Jika ini terus terjadi, maka dalam jangka panjang tentu akan mengubah pola interaksi mahasiswa tersebut didalam kehidupan sosial-bermasyarakat.

Mahasiswa Fakultas Ilmu Budaya Universitas Khairun yang adalah suatu komunitas terpelajar dengan fokus studi linguistik adalah objek dengan entitas yang unik, melihat sejauhmana pengaruh media sosial Facebook dalam aspek kebahasaan adalah upaya untuk mengukur bagaimana pergeseran dan pemertahanan bahasa terjadi di lingkungan akademis dengan fokus studi yang sama.

\section{MATERI DAN METODE}

\section{Media Sosial Facebook}

http://ejournal.unkhair.ac.id/index.php/humano 257 
Jurnal Penelitian Humano, Vol. 9 No. 2 Edisi November 2018

F.P William dalam bukunya Social Networking Sites : How to Stay Safe Sites: Multi-States Information Sharing \& Analysis Center (MSISAC) yang dikutip oleh Adam Mahamat Helou dan Nor Zairah Ab.Rahim dalam jurnal yang berjudul The Influence of Social Networking Sites on Students' Academic Performance in Malaysia mengemukakan, Sosial Networking Sites is an online community of internet users who want to communicate with other users about areas of mutual interest.

Jejaring sosial dapat dikatakan adalah struktur sosial yang terdiri dari elemen-elemen individual atau organisasi. Jejaring ini menunjukan jalan dimana mereka berhubungan karena kesamaan sosialitas, mulai dari mereka yang dikenal sehari-hari sampai dengan keluarga. Istilah ini diperkenalkan oleh profesor J.A. Barnes di tahun 1954 dalam tulisan Muhammad Ridwan Nawawi (2008).

Salah satu media sosial terkenal dan memiliki jumlah pengguna terbanyak adalah Facebook. Menurut wikipedia berbahasa Indonesia, Facebook adalah sebuah layanan jejaring sosial dan situs web yang diluncurkan pada 4 Februari 2004. Facebook didirikan oleh Mark Zuckerberg, seorang mahasiswa Harvard kelahiran 14 Mei 1984. Pada awal masa kuliahnya, situs jejaring sosial ini keanggotaannya masih dibatasi untuk mahasiswa dari Harvard College. Dalam dua bulan selanjutnya, keanggotaannya diperluas ke sekolah lain di wilayah Boston (Boston College, Universitas Boston, MIT, Tufts), Rochester, Stanford, NYU, Northwestern, dan semua sekolah yang termasuk dalam Ivy League. Sampai akhirnya, pada September 2006, Facebook mulai membuka pendaftaran bagi siapa saja yang memiliki alamat email (surat elektronik).

Fitur yang ditawarkan Facebook sebagai situs jejaring sosial membuat banyak orang menggunakannya. Menurut Wall Street Journal (2015), Indonesia merupakan salah satu pengguna Facebook terbesar dengan jumlah user/pengguna sekitar 70 juta orang.

\section{Bahasa dan Pergeseran Bahasa}

Bahasa merupakan suatu ungkapan yang mengandung maksud untuk menyampaikan sesuatu kepada orang lain. Sesuatu yang dimaksudkan oleh pembicara bisa dipahami dan dimengerti oleh pendengar atau lawan bicara melalui bahasa yang diungkapkan.

http://ejournal.unkhair.ac.id/index.php/humano 258 
Jurnal Penelitian Humano, Vol. 9 No. 2 Edisi November 2018

Chaer dan Agustina (1995:14) fungsi utama bahasa adalah sebagai alat komunikasi. Hal ini sejalan dengan Soeparno (1993:5) yang menyatakan bahwa fungsi umum bahasa adalah sebagai alat komunikasi sosial. Sosiolinguistik memandang bahasa sebagai tingkah laku sosial (sosial behavior) yang dipakai dalam komunikasi sosial.

Suwarna (2002: 4) bahasa merupakan alat utama untuk berkomunikasi dalam kehidupan manusia, baik secara individu maupun kolektif sosial. Kridalaksana (dalam Aminuddin, 1985: 2829) mengartikan bahasa sebagai suatu sistem lambang arbitrer yang menggunakan suatu masyarakat untuk bekerja sama, berinteraksi, dan mengidentifikasikan diri.

Effendi (1995:15) berpendapat bahwa pengalaman sehari-hari menunjukan bahwa ragam lisan lebih banyak daripada ragam tulis. Lebih lanjut Effendi (1995:78) menyampaikan bahwa ragam lisan berbeda dengan ragam tulis karena peserta percakapan mengucapkan tuturan dengan tekanan, nada, irama, jeda, atau lagu tertentu untuk memperjelas makna dan maksud tuturan. Selain itu kalimat yang digunakan oleh peserta percakapan tidak selalu merupakan kalimat lengkap.

Jeans Aitchison (2008 : 21) "Language is patterned system of arbitrary sound signals, characterized by structure dependence, creativity, displacement, duality, and cultural transmission", bahasa adalah sistem yang terbentuk dari isyarat suara yang telah disepakati, yang ditandai dengan struktur yang saling tergantung, kreatifitas, penempatan, dualitas dan penyebaran budaya.

Sedangkan Pergeseran bahasa (language shifting) yakni penggunaan bahasa oleh seorang penutur atau sekelompok penutur yang terjadi akibat perpindahan dari satu masyarakat tutur ke masyarakat tutur yang lain. Pergeseran bahasa umumnya mengacu pada proses penggantian satu bahasa dengan bahasa lain dalam repertoir linguistik suatu masyarakat. Dengan demikian, pergeseran bahasa mengacu pada hasil proses penggantian satu bahasa dengan bahasa lain. Sedangkan pemertahanan bahasa menyangkut masalah sikap atau penilaian terhadap suatu bahasa untuk tetap menggunakan bahasa tersebut di tengah-tengah bahasa lainnya. 
Jurnal Penelitian Humano, Vol. 9 No. 2 Edisi November 2018

Alasan perbedaan sosial yang menjadi hal utama untuk pilihan kode atau variasi dalam sebuah komunitas multilingual. Akan tetapi, apakah pilihan yang nyata bagi orang yang menggunakan bahasa lebih sedikit bahwasanya orangorang tersebut mempunyai bahasa yang lebih seperti bahasa Inggris? (Holmes, 2000: $55)$.

Holmes menyatakan bahwa ada dua kondisi masyarakat dengan sebuah bahasa mengalami pergeseran, yakni (a) migrant minorities, dan (b) nonmigrant communities. Kondisi pertama, pergeseran terjadi pada sebagian orang yangbermigrasi ke suatu tempat yang berbeda bahasanya; kondisi kedua pergeseranterjadi pada orang-orang bukan komunitas imigran (penduduk asli). Jadi,perubahan politik, ekonomi, dan sosial yang terjadi secara langsung dalamkomunitas dapat menyebabkan perubahan linguistik juga. (Holmes, 2000:57)

Pergeseran bahasa (language
shifting) atau pemertahanan bahasa
(language maintainance) dapat terjadi di
berbagai sektor kehidupan, misalnya
ekonomi, sosial, budaya, pendidikan, politik,
pemerintahan dan sebagainya.

Kedua peristiwa ini tentunya diikuti dengan bukti-bukti penggunaan bahasa masyarakat penuturnya. Kesadaran akan pendidikan, peningkatan kondisi ekonomi, dan mobilitas penduduk yang tinggi ternyata berpengaruh pada penggunaan bahasa sehari-hari.Dengan kemajuan teknologi komunikasi dan informasi, telah banyak memberikan pengaruh bagi perubahan atau pergeseran penggunaan bahasa tulisan dan lisan dalam pergaulan sehari-hari.

\section{Kerangka Konseptual}

Berdasarkan landasan teori yang telah dipaparkan, munculnya Facebook sebagai salah satu situs jejaring sosial yang sangat diminati oleh hampir seluruh masyarakat dunia juga berpengaruh terhadap penggunaan bahasa pergaulan pengguna Facebook itu sendiri. Sementara itu, di sisi yang lain bahasa yang digunakan dalam interaksi di Facebook adalah identitas sosial dan budaya yang pada saatnya nanti akan membentuk suatu gelombang kebudayaan yang secara berantai dan sistematis.

Perkembangan ini secara langsung akan memberikan dampak terhadap penggunaan bahasa Indonesia dan bahasa daerah. Baik itu dampak positif maupun negatif. Berikut adalah dampak yang 
Jurnal Penelitian Humano, Vol. 9 No. 2 Edisi November 2018

ditimbulkan oleh Media Sosial Facebook dalam aspek kebahasaan:

\subsection{Dampak Positif}

a. Meningkatnya pengetahuan masyarakat dunia terhadap bahasa Indonesia

Dengan perkembangan saat ini, dimana menurut catatan dari Wall Street Journal bahwa jumlah pengguna media sosial Facebook dari Indonesia menyentuh angka 70 juta, pengguna Ini tentu berpengaruh secara signifikan pada meningkatnya pengetahuan masyarakat dunia terhadap masyarakat dan bahasa Indonesia. Belum termasuk penyebaran massif melalui media lain, seperti melalui media televisi dan aplikasi sosial media global yang lain.

b. Meningkatnya produksi buku-buku terjemahan kedalam bahasa Indonesia Saat ini banyak buku dari luar-negeri yang diterjemahkan kedalam bahasa Indonesia, baik itu buku fisik maupun buku berbentuk ebook. Banyaknya buku terjemahan ini selain sebagai pengkayaan literature juga merupakan sebuah media pembauran kesusasteraan antar-bangsa.

c. Bertambahnya kosakata dalam Bahasa Indonesia
Secara langsung pertambahan jumlah kosakata bahasa Indonesia terjadi dengan sangat cepat. Hal ini terjadi dan mayoritas dipengaruhi oleh bahasa Inggris. Contoh: Information menjadi Informasi, Communication menjadi Komunikasi, Technology menjadi Teknologi, dan lain sebagainya.

d. Bahasa Indonesia sebagai kandidat bahasa Internasional

Berdasarkan jumlah penutur dan penggunaan di viral sosial, bahasa Indonesia termasuk yang terbesar diantara beberapa bahasa yang paling banyak penuturnya di dunia. Ini membuat bahasa Indonesia diwacanakan sebagai bahasa Pergaulan Internasional, ketertarikan dunia terhadap bahasa Indonesia tercermin dari bermunculannya pusat studi bahasa Indonesia di beberapa universitas-universitas terkemuka di dunia. Selain itu saat ini bahasa Indonesia menjadi yang paling berpotensi untuk dijadikan sebagai bahasa di komunitas negara-negara ASEAN (Association of South - East Asian Nation).

\subsection{Dampak Negatif}

a. Tidak lagi menggunakan bahasa Indonesia yang baik dan benar 
Jurnal Penelitian Humano, Vol. 9 No. 2 Edisi November 2018

Pola hidup masyarakat Indonesia yang konsumtif dan terbuka akan berakibat pada semakin mudahnya penerimaan terhadap berbagai penetrasi budaya luar, ini lebih mudah terjadi pada penggunaan bahasa Indonesia yang baik dan benar, salah satu contoh misalnya penggunaan media sosial oleh remaja, dimana kecenderungan remaja lebih suka menggunakan bahasa gaul di media sosial daripada bahasa Indonesia yang baik dan benar.

b. Tergerusnya budaya asli Indonesia Masyarakat global yang lebih terbuka menawarkan budaya baru yang lebih mudah dipilih oleh generasi muda yang sedang dalam proses pencarian jati-diri. Hal ini bermula dari terpengaruhinya bahasa Indonesia sebagai simbol dari jati diri bangsa yang disebabkan oleh pengaruh sosial media dan kemunculan game online yang menembus batas budaya antar-bangsa.

c. Hilangnya Kemurnian Bahasa Indonesia

Banyak masyarakat yang lebih bangga dan membangga-banggakan menggunakan bahasa asing. Atau malah mencampur-campur bahasa Indonesia dengan bahasa asing. Hal ini sering terjadi di masyarakat. Baik secara lisan maupun tulisan-tulisan pergaulan di dunia maya. Kata-kata seperti Good Morning, I Love You, Ganbatte, Arigatto, Sayonara, serta banyak kalimat populer lain lebih senang diucapkan dalam bahasa Inggris daripada bahasa Indonesia.

Dalam kondisi ini,tentulah diperlukan suatu strategi yang solutif untuk meminimalisir dampak negatif penggunaan sosial media Facebook agar kelak tidak memunculkan keadaan yang kontraproduktif, terutama pada mahasiswa Fakultas Sastra dan Budaya - Universitas Khairun.

\section{PEMBAHASAN}

\section{A. Lebih Jauh Mengenal Facebook}

Tinjauan tentang Media Sosial menggunakan pandangan F.P William dalam bukunya Social Networking Sites : How to Stay Safe Sites: Multi-States Information Sharing \& Analysis Center (MSISAC) yang dikutip oleh Adam Mahamat Helou dan Nor Zairah Ab.Rahim dalam jurnal yang berjudul The Influence of Social Networking Sites on Students' Academic Performance in Malaysia mengemukakan, Sosial Networking Sites is an online community of internet users who want to communicate with other users about areas of mutual interest. 
Jurnal Penelitian Humano, Vol. 9 No. 2 Edisi November 2018

Jejaring sosial dapat dikatakan adalah struktur sosial yang terdiri dari elemen-elemen individual atau organisasi. Jejaring ini menunjukan jalan dimana mereka berhubungan karena kesamaan sosialitas, mulai dari mereka yang dikenal sehari-hari sampai dengan keluarga. Istilah ini diperkenalkan oleh profesor J.A. Barnes di tahun 1954 dalam tulisan Muhammad Ridwan Nawawi (2008: 26).

Salah satu media sosial terkenal dan memiliki jumlah pengguna terbanyak adalah Facebook. Menurut wikipedia berbahasa Indonesia, Facebook adalah sebuah layanan jejaring sosial dan situs web yang diluncurkan pada 4 Februari 2004. Facebook didirikan oleh Mark Zuckerberg, seorang mahasiswa Harvard kelahiran 14 Mei 1984. Pada awal masa kuliahnya, situs jejaring sosial ini keanggotaannya masih dibatasi untuk mahasiswa dari Harvard College. Dalam dua bulan selanjutnya, keanggotaannya diperluas ke sekolah lain di wilayah Boston (Boston College, Universitas Boston, MIT, Tufts), Rochester, Stanford, NYU, Northwestern, dan semua sekolah yang termasuk dalam Ivy League. Sampai akhirnya, pada September 2006, Facebook mulai membuka pendaftaran bagi siapa saja yang memiliki alamat email (surat elektronik). Fitur yang ditawarkan Facebook sebagai situs jejaring sosial membuat banyak orang menggunakannya. Menurut Wall Street Journal (2015), Indonesia merupakan salah satu pengguna Facebook terbesar dengan jumlah user/pengguna sekitar 70 juta orang.

Ketika pertama kali log in di http/www.facebook.com, maka akan muncul gambar dengan tampilan berwarna biru. Bagi mereka yang belum punya facebook dan memiliki alamat e-mail yang masih aktif dan ingin menjadi user facebook cukup dengan mengisi data pada kolom-kolom yang disediakan. Namun bagi sudah memiliki akun tinggal mengisi alamat email dan kata sandi pada kolom yang telah disediakan lalu mengklik tombol log in.

Setelah pengguna $\log$ in, maka pengguna dapat berinteraksi dengan sesama teman facebook serta memanfaatkan semua fitur-fitur yang ada. Pengguna dapat membuat profil dilengkapi foto, daftar ketertarikan pribadi, informasi kontak, dan informasi pribadi lain. Pengguna dapat berkomunikasi dengan teman dan pengguna lain melalui pesan pribadi atau umum dan fitur obrolan. Mereka juga dapat membuat dan bergabung dengan grup ketertarikan dan "halaman kesukaan" (dulu disebut "halaman 
Jurnal Penelitian Humano, Vol. 9 No. 2 Edisi November 2018

penggemar" hingga 19 April 2010), beberapa di antaranya diurus oleh banyak organisasi dengan maksud beriklan.

Facebook memiliki sejumlah fitur yang dapat berinteraksi dengan pengguna. Salah satunya adalah Dinding, kotak di setiap halaman profil pengguna yang mengizinkan teman mereka mengirimkan pesan kepada pengguna tersebut. Selain itu ada juga fitur Colek, yang memungkinkan pengguna mengirimkan "colekan" virtual satu sama lain (pemberitahuan memberitahu pengguna bahwa mereka telah dicolek); Foto, tempat pengguna dapat mengunggah album dan foto; dan Status, yang memungkinkan pengguna untuk memberitahukan teman mereka mengenai keberadaan dan tindakan mereka saat itu. Tergantung pengaturan privasinya, setiap orang yang dapat melihat sebuah profil pengguna dapat juga melihat Dinding pengguna. Bulan Juli 2007, facebook mulai mengizinkan pengguna mengirimkan lampiran di Dinding, berbeda dari Dinding sebelumnya yang terbatas pada konten teks saja.

Sepanjang waktu, facebook menambahkan fitur ke situsnya. Facebook Notes diperkenalkan pada 22 Agustus 2006, sebuah fitur blog yang mengizinkan tag dan penanaman gambar. Pengguna dapat mengimpor blog dari Xanga, LiveJournal, Blogger, dan layanan blog lain. Sepanjang minggu 7 April 2008, facebook merilis aplikasi pesan instan berbasis Comet bernama "Chat" ke sejumlah profil, yang mengizinkan pengguna berkomunikasi dengan teman dan fungsinya sama seperti pengantar pesan instan berbasis desktop.

Pada 6 September 2006, News Feed diluncurkan yang ditempatkan di setiap halaman utama pengguna dan memberitahukan informasi seperti perubahan profil, acara berikutnya, dan ulang tahun teman pengguna. Hal ini memungkinkan pengirim spam dan pengguna lain memainipulasi fitur-fitur tersebut dengan membuat acara bohong atau ulang tahun bohong demi menarik perhatian ke profil atau kampanye tersebut. Awalnya, News Feed memunculkan ketidakpuasan di antara pengguna facebook; sejumlah di antaranya mengeluh karena terlalu berantakan dan penuh dengan informasi yang tidak perlu, sementara pengguna lain menganggapnya mudah bagi pengguna untuk melacak aktivitas seseorang (seperti perubahan status hubungan, acara, dan percakapan dengan pengguna lain). Namun untuk fitur ini, Zuckerberg mengirimkan 
Jurnal Penelitian Humano, Vol. 9 No. 2 Edisi November 2018

permintaan maafnya atas kegagalan situs ini untuk memasukkan fitur privasi yang dapat diatur sendiri. Sejak itu, pengguna mulai mendapat kontrol terhadap jenis-jenis informasi apa saja yang dapat dibagikan secara otomatis kepada teman.

\section{B. Bahasa Didalam Media Sosial Facebook}

Kegiatan sosialisasi pengaruh Facebook terhadap penggunaan bahasa terhadap interaksi mahasiswa Fakultas Sastra dan Budaya dilanjutkan dengan pengenalan konsep bahasa didalam media sosial Facebook, melalui ini mahasiswa diberikan pemahamann bahwa bahasa adalah salah satu unsur kebudayaan yang berarti di dalamnya tercermin nilai-nilai yang berhubungan dengan kehidupan manusia sebagai makhluk sosial. Dalam kedudukannya manusia sebagai makhluk sosial, maka bahasa menjadi media komunikasi dalam interaksi sosial. Dalam interaksi sosial tersebut, dibutuhkan komunikasi yang baik (efektif), agar pesan yang disampaikan dalam komunikasi dapat diterima dengan baik oleh penerima pesan. Berkaitan dengan baik tidaknya proses komunikasi terdapat aturan main (rule of the game) yang perlu diperhatikan oleh mereka yang terlibat dalam komunikasi tersebut.
Proses komunikasi sosial kadang kala di dalamnya muncul persoalan etis yang melibatkan hubungan antar individu, baik menyangkut hubungan antar individu dalam keluarga, masyarakat, maupun hubungan dalam komunitas atau kelompok tertentu. Persoalan tersebut muncul ketika komunikasi yang terjadi antara individu yang satu dengan individu lainnya menimbulkan perasaan tidak nyaman bagi salah satu atau kedua individu yang terlibat, sehingga dapat mempengaruhi sikap dan tindakan mereka selanjutnya.

Teknologi komunikasi yang bergerak sangat cepat dalam jalan tol cyberspace itu menyebabkan terjadinya impuls sosial budaya yang sangat beragam, saling tumpang tindih, dan pada akhirnya memicu proses pencampuradukkan berbagai wacana nilai ke dalam wacana posmodernisme sebagai sebuah tindakan irasional, ekletik, dan pluralitas (Hadi, 2005:85). Hal tersebut kemudian mengisyaratkan perubahan dan keunikan, sekaligus keganjilan pada realitas tanda (sign) dan makna sebagai sebuah unsur penting dalam bahasa dan komunikasi, yang secara hermeneutis memiliki peranan sentral dalam proses memahami (Dalam The Conflict of Interpretations, Paul Ricoeur mengatakan bahwa pemahaman bahasa 
Jurnal Penelitian Humano, Vol. 9 No. 2 Edisi November 2018

(pada tingkat ontologis) pada hakikatnya adalah 'cara berada' atau 'cara menjadi' yang menunjukkan hakikat keberadaan makna itu sendiri).

Konteks ini menyebabkan terjadinya kehadiran sesuatu yang baru berkaitan dengan ruangnya sendiri. Realitas maya, dengan kata lain, tampaknya telah membentuk bahasa mayanya sendiri, campuran kata benda verbal, akronim yang panjang, mutasi aneh yang lahir dari jargon pascastrukturalisme dan budaya pop, teori informasi, dan infotainment (information entertainment).

Harus diakui bahwa etika berbicara baik itu di dunia nyata maupun di dunia maya memiliki korelasi, dimana tidak boleh ada pembedaaan diantara keduanya. Kecenderungan yang niscaya adalah cara berbahasa atau etika berbicara seseorang di media sosial facebook mencerminkan dirinya yang sebenarnya di dunia nyata, yang membedakan hanyalah bahasa yang dipergunakan (bahasa Indonesia), baku tidaknya, etis dan tidak etisnya.

Sebagai wahana komunikasi, jelas bahasa memiliki peranan penting, termasuk didalam komunikasi di facebook. Sebagaimana komunikasi di dunia nyata,facebook juga memiliki aturan etis tersendiri bagi para penggunanya, terlebih facebook adalah media komunikasi multipersonal yang memungkinkan interaksi tidak terbatas hanya pada antar-individu. Salah satu fitur di facebook yakni 'status' adalah media komunikasi masal yang dapat dibaca/menghubungkan pengguna facebook yang berteman dalam durasi waktu yang tidak terbatas. Oleh karena sifatnya yang demikian, maka fitur status di facebook mampu mengarahkan pola komunikasi dan seluruh perangkat bahasa yang digunakan oleh satu seorang pengguna untuk dapat diikuti oleh pengguna lain.

\section{Pengaruh Facebook Terhadap Pola}

\section{Kebahasaan Mahasiswa Ilmu Budaya}

Pemahaman tentang fakta-fakta atau data-data yang sebelumnya telah dikumpulkan oleh pengelola kegiatan dan telah disajikan dalam bentuk materi. Adapun materi yang disampaikan berupa fakta pengaruh faecbook terhadap pola kebahasaan pada mahasiswa Fakultas Ilmu Budaya.

Sebagaimana yang diketahui bahwa bahasa Indonesia merupakan bahasa yang baku yang mempunyai kaidah-kaidah disetiap penulisan maupun pengucapannya. Bahasa Indonesia ini bahasa yang mudah dimengerti oleh semua orang, meskipun 
Jurnal Penelitian Humano, Vol. 9 No. 2 Edisi November 2018

mereka berasal dari daerah yang berbeda.

Dalam perkembangannya, Bahasa Indonesia sebagai bahasa nasional secara otomatis menjadi bahasa pergaulan di media sosial termasuk facebook, keberadaan bahasa Indonesia bagi komunikasi interpersonal pengguna facebook di Indonesia sama pentingnya dengan bahasa Inggris dalam komunikasi interpersonal masyarakat dunia di facebook karena dapat dimengerti oleh semua penggunanya.

Ini tidak terkecuali juga dengan mahasiswa di Fakultas Ilmu Budaya Universitas Khairun yang terdiri dari latar belakang yang berbeda antara satu dengan yang lain, baik itu suku, etnis, yang masingmasing memiliki bahasa dan dialek yang berbeda. Bahasa Indonesia sudah pasti dijadikan sebagai bahasa pengantar di facebook disamping Bahasa Melayu Ternate (BMT) yang lebih mudah dimengerti secara kolektif.

Dengan bahasa Indonesia yang
secara umum digunakan, dapat
memungkinkan terbangunnya interaksi di
media sosial facebook antar sesama
mahasiswa Fakultas Ilmu Budaya pengguna
facebook, hal ini dapat memperlancar
pertemanan antar individu maupun
kelompok, antara teman angkatan, kelas,

jurusan, hingga sesama pengurus organisasi intra fakultas yang berada di Fakultas Ilmu Budaya.

Namun begitu sifat komunikasi di facebook yang multi-personal berimbas pula pada penggunaan dan keberadaan bahasa Indonesia oleh mahasiswa di Fakultas Ilmu Budaya. Sebagai contoh, penggunaan bahasa Indonesia di ranah facebook ini, memberi banyak perubahan bagi struktur bahasa Indonesia yang oleh beberapa pihak disinyalir merusak bahasa itu sendiri. Hal tersebut memunculkan istilah baru, yaitu 'Indoglish' kependekan dari 'IndonesianEnglish' untuk fenomena bahasa yang kian menghantam bahasa Indonesia.

Penggunaan bahasa Indonesia berdampingan dengan bahasa Inggris bagi beberapa mahasiswa Program Studi Sastra Inggris secara langsung adalah merupakan pengaruh dari penggunaan facebook itu sendiri, sebab kecenderungan mahasiswa melihat trend dari status-status yang ditampilkan oleh teman facebooknya, meskipun memang sedikit dipengaruhi oleh latar-belakang pendidikan mahasiswa tersebut di program studi Sastra Inggris. Ada kecenderungan menggunakan bahasa campur antara Inggris-Indonesia dalam status facebook bukan dengan maksud untuk 
Jurnal Penelitian Humano, Vol. 9 No. 2 Edisi November 2018

menunjukkan bahwa yang bersangkutan menguasai bahasa Inggris, tetapi sekedar ikut-ikutan.

Fenomena di atas dapat mengakibatkan pergeseran bahasa Indonesia yang digunakan di facebook. Secara umum, fenomena pergeseran bahasa sebenarnya telah ada sejak bahasa-bahasa itu mulai mengadakan kontak dengan bahasa lainnya (Grosjean, 1982: 75). Kontak antardua suku atau suku bangsa yang digunakan oleh dua individu komunikator yang masing-masing membawa bahasanya sendiri-sendiri lambat laun mengakibatkan terjadinya persaingan kebahasaan. Pada umumnya, di dalam persaingan kebahasaan terjadi fenomenafenomena kebahasaan yang diawali dengan kedwibahsaan, diglosia, alih kode/campur kode, interferensi, dan akhirnya permertahanan dan pergeseran bahasa. Jika satu bahasa lebih dominan, lebih berprestise, atau lebih modern atau bahkan mungkin lebih "superior" daripada bahasa lain, bahasa tersebut dipastikan dapat bertahan, sedangkan lainnya dalam beberapa generasi akan ditinggalkan oleh penuturnya. Tidak jarang bahasa yang ditelantarkan oleh penuturnya itu lambat laun mengakibatkan kematian bahasa.
Dalam kepustakaan sosiolinguistik, pergeseran bahasa merupakan fenomena yang menarik. Terminologi pergeseran bahasa pertama kali diperkenalkan oleh Fishman pada tahun 1964 yang selanjutnya dikembangkan oleh Susan Gal yang meneliti masalah pilihan dan pergeseran bahasa di Oberwart, Austria timur pada tahun 1979, dan Nancy Dorian yang mengkaji pergeseran bahasa Gaelik oleh bahasa Inggris di Sutherland Timur, Britania bagian utara pada tahun 1981. Pergeseran bahasa erat kaitannya dengan ranah yang berkaitan dengan pilihan bahasa dan kewibahasaan.

Kajian pergeseran bahasa perlu dikaitkan dengan konsep pemilihan bahasa. Pemahaman tentang pilihan bahasa dalam ranah yang dihubungkan dengan konsep diglosia di atas sangat penting artinya karena dengan begitu pemertahanan dan kebocoran diglosia yang menyebabkan pergeseran bahasa dapat dilihat. Pergeseran bahasa serta kepunahan suatu bahasa bertitik-tolak dari kontak dua bahasa dalam suatu masyarakat. Gejala kepunahan bahasa akan tampak dalam proses yang cukup panjang. Mulamula tiap-tiap bahasa masih dapat mempertahankan pemakaiannya pada ranah masing-masing. Kemudian pada suatu masa transisi masyarakat tersebut menjadi 
Jurnal Penelitian Humano, Vol. 9 No. 2 Edisi November 2018

dwibahasawan sebagai suatu tahapan sebelum kepunahan bahasa aslinya dan dalam jangka waktu beberapa generasi mereka bertrasformasi menjadi masyarakat ekabahasawan kembali. Dengan demikian, pergeseran bahasa mencakup pertamapertama kedwibahasaan (seringkali bersama diglosia) sebagai suatu tahapan menuju keekabahasaan.

Ada banyak faktor yang menyebabkan pergeseran. Berdasarkan hasil-hasil penelitian yang telah dilakukan di berbagai tempat di dunia, faktor-faktor tersebut seperti loyalitas bahasa, konsentrasi wilayah pemukiman penutur, pemakaian bahasa pada ranah tradisional sehari-hari, kesinambungan peralihan bahasa-ibu antargenerasi, pola-pola kedwibahasaan, mobilitas sosial, sikap bahasa dan lain-lain. Faktor-faktor itu juga dapat berupa kekuatan kelompok mayoritas terhadap kelompok minoritas, kelas sosial, latar belakang agama dan pendidikan, hubungan dengan tanah leluhur atau asal, tingkat kemiripan antara bahasa mayoritas dengan bahasa minoritas, sikap kelompok mayoritas terhadap kelompok minoritas, perkawinan campur, kebijakan politik pemerintah terhadap bahasa dan pendidikan kelompok minoritas, serta pola pemakaian bahasa.
Sesungguhnya, terdapat banyak faktor yang dapat menyebabkan terjadinya pergeseran bahasa di masyarakat. Namun, faktor-faktor itu bervariasi antarsatu wilayah dengan wilayah lainnya. Faktor-faktor penyebab terjadinya kasus pergeseran bahasa di Oberwart-Austria berbeda dari faktor-faktor penyebab atas kasus yang sama di Sutherland-Scotlandia ataupun kasus pergeseran dan pemertahanan bahasa Lampung di Lampung. Grosjean (1982:107) mengelompokkan faktor-faktor itu ke dalam lima faktor: sosial, sikap, pemakaian, bahasa, kebijakan pemerintah, dan faktorfaktor lain. Adanya pola-pola sosial dan budaya yang beragam dalam suatu masyarakat ikut menentukan identitas sosial dan keanggotaan kelompok sosialnya, faktor-faktor sosial itu meliputi status sosial, kedudukan sosial ekonomi, umur, jenis kelamin, tingkat pendidikan, pekerjaan atau jabatan, serta keanggotaan seseorang dalam suatu jaringan sosial.

Facebook sebagai suatu jaringan sosial memiliki pengaruh yang sangat besar bagi proses pergeseran bahasa ini, dalam tahap selanjutnya kondisi yang terjadi di dunia maya ini mungkin saja akan berdampak pada pola komunikasi atau penggunaan bahasa mahasiswa yang 
Jurnal Penelitian Humano, Vol. 9 No. 2 Edisi November 2018

bersangkutan di dunia nyata (di kampus).

Dalam konteks ini, penggunaan bahasa Indonesia yang berdampingan dengan bahasa Inggris yang secara terus-menerus di Facebook selanjutnya akan membentuk trend baru yang bersampingan dengan trend Bahasa Alay atau Language disorder.

Secara umum cara berinteraksi di facebook dalam kaitannya dengan pemilihan gaya bahasa sama saja dengan yang terjadi di dunia nyata atau di lingkungan kampus, kemungkinan facebook dapat membentuk pola bahasa tersendiri atau berpengaruh terhadap penggunaan bahasa dalam kehidupan sehari-hari, intinya adalah cara berbahasa di dunia nyata dan di facebook sama. Yang membedakan hanyalah bahasa lisan dan bahasa tulisan.

Facebook secara langsung memiliki pengaruh yang secara sistematis membentuk pola pemakaian bahasa yang digunakan, namun demikian status sebagai mahasiswa Fakultas Ilmu Budaya dengan latar belakang pendidikan kebahasaan yang mumpuni, dampaknya di dunia nyata tidak begitu nampak, terlebih untuk mahasiswa yang aktif dalam berorganisasi, dimana sebisa mungkin menggunakan bahasa Indonesia yang baku disamping penggunaan Bahasa
Melayu Ternate (BMT) dalam setiap aktifitas di kampus.

Dunia pendidikan yang syarat pembelajaran dengan media bahasa menjadikan bahasa sebagai alat komunikasi yang primer. Sejalan dengan hal tersebut, bahasa baku merupakan simbol dalam dunia pendidikan dan cendekiawan. Penguasaan Bahasa Indonesia yang maksimal dapat dicapai jika fundasinya diletakkan dengan kokoh di rumah dan di sekolah mulai TK (Taman Kanak-kanak) sampai PT (Perguruan Tinggi). Akan tetapi, fondasi ini pada umumnya tidak tercapai. Di berbagai daerah, situasi kedwibahasaan merupakan kendala. Para guru kurang menguasai prinsip-prinsip perkembangan bahasa anak sehingga kurang mampu memberikan pelajaran bahasa Indonesia yang serasi dan efektif.

Terkait dengan ini, Rusyana, (1984:152) menyatakan bahwa dalam membina masyarakat akademik, penggunaan bahasa yang tidak baik dan tidak benar akan menimbulkan masalah. Penggunaan bahasa Indonesia yang baik dan benar di media sosial dianggap mempunyai peranan dalam menuju arah pembangunan masyarakat akademik idaman. 
Jurnal Penelitian Humano, Vol. 9 No. 2 Edisi November 2018

Kurangnya pemahaman terhadap variasi pemakaian bahasa berimbas pada kesalahan penerapan berbahasa baik di dunia nyata maupun di dunia maya. Secara umum dan nyata perlu adanya kesesuaian antara bahasa yang dipakai dengan tempat berbahasa. Tolok ukur variasi pemakaian bahasa adalah bahasa Indonesia yang baik dan benar dengan parameter situasi. Bahasa Indonesia atau bahasa lainnya yang baik dan benar adalah bahasa Indonesia yang digunakan sesuai dengan norma yang berlaku dan sesuai dengan kaidah-kaidah bahasa Indonesia (atau bahasa lain yang dipergunakan) (Sugono, 1994: 8).

\section{Abreviasi di Facebook}

Pada sesi selanjutnya peserta sosialisasi diberikan pemahaman mengenai penggunaan abreviasi yang secara tidak sadar telah dilakukannya di media sosial facebook secara terus-menerus. Adapun Abreviasi merupakan proses morfologis yang berupa penanggalan satu atau beberapa bagian leksem atau kombinasi leksem sehingga jadilah bentuk baru yang berstatus kata (Kridalakasana, 2001: 1). Sementara itu, dalam Kamus Besar Bahasa Indonesia, menjelaskan bahwa abreviasi adalah pemendekan bentuk sebagai pengganti bentuk yang lengkap, atau bentuk singkatan tertulis sebagai pengganti kata atau frasa.

Abreviasi kata dalam frasa biasanya dipakai untuk menghemat waktu mengetik untuk beberapa penggalan kata yang secara umum sudah dipahami oleh lawan interaksi di facebook. Adapun Abreviasi yang biasanya digunakan adalah jenis prefiks, yakni afiks yang diimbuhkan di sebelah kiri dasar. Salah satu contoh prefiks bahasa Indonesia adalah $\{m e N-\}$ seperti mendapat, mencuri, menyalak. Salah satu contoh prefiks bahasa Inggris adalah $\{$ un- $\}$ seperti uneasy, uncomfortable. Heymann Steinthal (dalam Keraf, 1990: 68) berpendapat bahwa bahasa yang memiliki prefiks adalah bahasa Polinesia. Teknik analisis dengan cara memilah kata yang mengalami proses perubahan prefiks dengan menghilangkan satu atau beberapa huruf maupun dengan menggunakan tanda baca. Kata dasar keluh, upload, dan urus mendapat prefiks meNsehingga menjadi mengeluh, mengupload dan mengurus kemudian mengalami perubahan prefiks $n g$ - sehingga menjadi ngeluh, ngupload dan ngurus. Kata dasar jalan, cinta dan diri mendapat prefiks bersehingga menjadi berjalan, bercinta dan berdiri kemudian mengalami perubahan prefiks $b$ '- sehingga menjadi b'jalan, b'cinta 
Jurnal Penelitian Humano, Vol. 9 No. 2 Edisi November 2018

dan b'diri, kata b'jalan mengalami penghilangan fonem lal pada suku kata pertama kata dasar sehingga menjadi b'jlan, kata b'cinta mengalami penambahan fonem lal di bagian akhir sehingga menjadi b'cintaa. Kata capai, jadi dan datang mendapat prefiks $m e N$ - sehingga menjadi mencapai, menjadi dan mendatang kemudian mengalami perubahan prefiks $m n-$ sehingga menjadi mncapai, mnjadi dan mndatang, kata mncapai dan mnjadi mengalami penghilangan fonem vokal pada suku kata pertama kata dasar sehingga menjadi mncpai dan mnjdi. Kata ingat, indah dan baik mendapat prefiks tersehingga menjadi teringat, terindah dan terbaik kemudian mengalami perubahan prefiks $t r$ - sehingga menjadi tringat, trindah dan trbaik. Kata suruh, beri, dan sangka mendapat prefiks $d i$ - sehingga menjadi disuruh, diberi, dan disangka kemudian mengalami perubahan prefiks $d$ - sehingga menjadi dsuruh, dberi, dan dsangka. Kata hasil dan usaha mendapat prefiks bersehingga menjadi berhasil dan berusaha kemudian mengalami perubahan prefiks $b r$ sehingga menjadi brhasil dan brusaha, kata brusaha mengalami penghilangan fonem /a/ pada suku kata kedua kata dasar sehingga menjadi brusha.
Penyingkatan berupa abreviasi prefiks ini mungkin saja terjadi karena mengikuti kata yang ditulis oleh teman facebook dalam statusnya, namun pada umumnya dilakukan karena mempertimbangkan penyingkatan waktu dan tenaga didalam mengetik tombol perangkat yang dipergunakan.

\section{E. Alay di Facebook}

Sesi ini menjelaskan tentang suatu fenomena yang berkaitan dengan aspek kebahasaan di Facebook yakni fenomena Alay yang kemudian secara berkelanjutan menjadi fenomena juga di dunia nyata. Yang pertama digunakan untuk menggambarkan fenomena ini adalah teori Ben Anderson yang menjelaskan bahwa tidak peduli apakah sebuah masyarakat berbeda keyakinan, rasa, dan suku, atau di antara mereka tidak akan pernah tahu dan mengenal satu dengan lainnya, tidak pernah bertatap muka, atau bahkan mungkin tidak pernah mendengar tentang mereka, namun mereka adalah sebuah satu komunitas (yang terbayang) (Anderson dalam Young, 2007:37). Artinya adalah di benak setiap orang yang menjadi bagian dari masyarakat itu, mereka hidup dalam sebuah bayangan tentang kebersamaan.

http://ejournal.unkhair.ac.id/index.php/humano 272 
Jurnal Penelitian Humano, Vol. 9 No. 2 Edisi November 2018

Di dalam situs jejaring sosial seperti

Facebook, keberadaan Alay setidaknya bisa dideteksi lewat generalisasi perilaku yang berkaitan dengan pola bahasa Alay. Yang pertama, kegemaran mereka untuk 'perang dinding' (wall) adalah salah satu fasilitas di Facebook yang memungkinkan orang lain untuk menulis komentar di account user dan bisa dibaca oleh user yang lain. Hal ini berbeda dengan fasilitas message yang hanya bisa diakses oleh si pemilik account dan pengirim pesan. Istilah perang dinding bisa diartikan sebagai berbalas komentar di dinding Facebook, biasanya hal tersebut dimaksudkan untuk kesenangan saja, dengan user Facebook yang lain. Kedua adalah pemakaian bahasa Alay yang sulit dimengerti oleh user yang lain, karena bahasa Alay mencampuradukkan antara huruf dengan simbol serta pemakaian tanda baca yang tak beraturan.

Fenomena Alay adalah bagian lain dari pengaruh facebook dari aspek pola kebahasaan, dimana hubungan interpersonal yang sedemikian luas membentuk suatu paradigma kebahasaan baru yang kemudian dianut secara berantai oleh setiap pengguna yang ada di facebook, terlebih bagi para pelajar dan mahasiswa. Ini juga tidak terkecuali oleh mahasiswa Fakultas
Sastra dan Budaya Universitas Khairun yang aktif di Facebook.

Kebanyakan mahasiswa di Fakultas Ilmu Budaya yang terhubung melalui facebook yang aslinya adalah pendiam di kampus, tetapi ketika di facebook sering memasang status yang alay atau ungkapanungkapan berupa curhatan yang sangat tidak perlu dengan gaya bahasa yang juga tidak perlu.

Tabel 1.

Contoh Kosakata Alay

\begin{tabular}{|l|l|}
\hline \multicolumn{1}{|c|}{ Bahasa Indonesia } & \multicolumn{1}{|c|}{ Bahasa Alay } \\
\hline Gue & W, Wa, Q, G, Gw \\
\hline Rumah & Humz \\
\hline Ya/Iya & Yups, Yap, Iap \\
\hline Nih & Nich, Nieh, Nieyh \\
\hline Tuh & Tuch, Thu \\
\hline Lagi & Ghy, Ghe, Gy \\
\hline Love & Luph, Lv, Loph \\
\hline Tempat & T4 \\
\hline Sempat & S4 \\
\hline
\end{tabular}

Menurut Baudrillard, fenomena Alay muncul sebagai orientasi simulasi, yakni pola yang dikontrol oleh kode-kode dan sebuah fase yang didominasi oleh reproduksi dari realitas buatan (hiperrealitas). Artinya, bahasa cyberspace adalah ungkapan serta perilaku simulatif dari seseorang berupa 
Jurnal Penelitian Humano, Vol. 9 No. 2 Edisi November 2018

penyalahgunaan dan pembajakan tandatanda (sign) sebagai sebuah mekanisme representasi dan bahasa.

Menurutnya, model produksisimulasi (yang menjadi fase dominan era informasi saat ini tidak saja menghasilkan objek hyperreal, namun juga objek kompresi dan dekonstruksi), adalah sebuah teori pembongkaran yang dikembangkan terhadap kode-kode bahasa, khususnya sistem oposisi biner, yang kemudian melahirkan permainan tanda (dan juga bahasa) tanpa akhir dan makna akhir (Piliang, 2003:142-149). Dalam konsep kedua ini, bahasa Alay dilihat sebagai sebuah dekonstruksi atas tandatanda kebahasaan yang normal, yang sebenarnya tidak memiliki makna tertentu serta makna akhir. Makna adalah lapisan kedua yang ingin mereka capai. Tujuan utama mereka hanyalah mengobrak-abrik bahasa yang sudah ada, dan menggantinya dengan sistem tanda serta simbol ala mereka.

Meski begitu, Penggunaan bahasa alay atau ungkapan alay di Facebook tidak mencerminkan bahwa yang bersangkutan juga menggunakan ungkapan alay di dunia nyata atau menggunakan media komunikasi lainnya baik lisan maupun tulisan. Proses ini biasanya terjadi karena yang bersangkutan kurang begitu memahami bahasa yang digunakan atau belum tahu tentang nilainilai etis dalam berbahasa, terlebih dalam kapasitasnya sebagai mahasiswa Fakultas Sastra dan Budaya dengan kajian linguistik yang lumayan kuat.

Di Fakultas Ilmu Budaya, penggunaan bahasa Alay di media sosial Facebook oleh mahasiswa yang aktif di Facebook cenderung dilakukan oleh mahasiswa yang baru terdaftar (baru lulus SMA). Dalam hal ini berarti bahwa Alay sebagai bahasa cyberspace telah beranggungjawab dalam memproduksi dan menstimulasi simbol kebahasaan lewat produksi citra atau simulasi tanda. Jadi, dalam konteks Alay, setiap makna dan tanda atau citra tidak lagi mengacu pada realitas yang sesungguhnya. Ia hanya merupakan permainan bahasa yang tidak ditujukan untuk mencapai komunikasi pesan yang efektif dan kedalaman makna komunikasi itu sendiri. Ia hanya menciptakan kesenangan bermain dengan bahasa dan kenikmatan yang kemudian disebut Roland Barthes sebagai jouissance, atau yang diistilahkan Baudrillard sebagai 'ekstasi komunikasi'. Hal ini kurang lebih sama dengan logika permainan bahasa di era posmodern, di mana bahasa metaforis ikut bermain. 
Jurnal Penelitian Humano, Vol. 9 No. 2 Edisi November 2018

Keunikannya terletak pada ambiguitasnya, pada kandungan unsur-unsur kontras di dalamnya. Ini biasanya dilakukan oleh mereka yang tidak mengetahuinya/sekedar ikut-ikutan.

Ini juga menegaskan bahwa fenomena bahasa alay di media sosial facebook memiliki implikasi terhadap pengetahuan pelaku yang berperilaku alay. Dimana rata-rata narasumber yang terdiri dari mahasiswa Fakultas Sastra dan Budaya pengguna aktif facebook mengakui bahwa tidak menggunakan bahasa alay didalam status facebook maupun berkirim pesan. Hal ini dikarenakan pengetahuan dan latar belakang pendidikan yang kuat di bidang linguistik, sehingga bahasa alay dianggap sebagai penyimpangan didalam identitas berbahasa.

\section{PENUTUP}

\section{A. Kesimpulan}

Hasil dari uraian ini dapat dibuat kesimpulan sebagai berikut:

a. Adanya peningkatan pengetahuan para mahasiswa, khususnya mengenai dampak penggunaan sosial media facebook terutama pada mahasiswa Fakultas Ilmu Budaya Universitas Khairun. b. Pengetahuan kebahasaan membuat seseorang dalam aplikasinya tidak terlalu terpengaruh oleh berbagai fenomena anomali kebahasaan di facebook.

c. Media Sosial Facebook sebagai ruang interaksi dapat menyebabkan terjadinya pergeseran bahasa, dimana rata-rata mahasiswa Fakultas Ilmu Budaya ataupun yang berlatarbelakang studi kebahasaan lainnya harus lebih memahami hal tersebut.

d. Secara umum pengaruh facebook dalam aspek bahasa terhadap mahasiswa Fakultas Ilmu Budaya Universitas Khairun sangatlah kecil, dimana justru pengetahuan berdasarkan latar-belakang pendidikan yang ditempuh oleh mahasiswa di Fakultas Ilmu Budaya yang lebih mempengaruhi pola penggunaan bahasa mereka di Facebook. Hal ini juga terlihat pada fenomena penggunaan bahasa alay yang tidak terlalu mempengaruhi mahasiswa Fakultas Sastra dan Budaya pengguna facebook.

e. Penggunaan abreviasi di facebook menjadi dominan karena kebutuhan untuk mempersingkat waktu dan 
Jurnal Penelitian Humano, Vol. 9 No. 2 Edisi November 2018

jumlah karakter yang akan diketik oleh mahasiswa pengguna facebook, beberapa narasumber mengatakan bahwa itu dilakukan karena menerapkan insting, yakni keterbiasaan yang mungkin saja didapatkan karena terbiasa membaca status-status teman facebook yang umumnya menggunakan abreviasi berupa prefiks untuk beberapa kata yang menggunakan imbuhan yang biasanya adalah kata kerja.

\section{B. Saran}

Olehnya disarankan:

a. Perlu kiranya dilakukan sosialisasi lanjutan yang secara intensif dapat menjangkau khalayak mahasiswa yang lebih luas.

b. Kepada mahasiswa agar dapat lebih bijaksana dalam menggunakan facebook sebagai sarana komunikasi inter-personal dan memahami berbagai fenomena yang muncul olehnya.

\section{Daftar Pustaka}

Abdullah. Aceng. 2000. Press relations, kiat berhubungan dengan media massa. Bandung: Remaja Rosdakarya.

Aitchison, Jean. 2008. Linguistics. London : Hodder Headline
Balack. James dan Dean J. Champion, 1992. Metode dan Masalah Penelitian Sosial. Bandung: Eresco.

Bonar. S.K. 1983. Hubungan Masyarakat Modern. Jakarta: Bumi Aksara

Branen. Julia, 1997. Memandu Penelitian Kualitatif dan Kuantitatif. Yogyakarta: Pustaka Belajar.

Chaer, Abdul \& Leonie Agustina. 1995. Sosiolinguistik Perkenalan Awal. Jakarta: Rineka Cipta

Effendi, Drs. 1995. Tata Bahasa Praktis Bahasa Indonesia. Jakarta : PT Rineka Cipta.

F.P.William. 2009. Social networking sites: How To Stay Safe Sites: MultiState Information Sharing \& Analysis Center (MS-ISAC) http://www.msisac.org,Stay Safe So October 6, 2010 by Sorav Jain, (40 Most Popular Social Networking Sites of the World)

Hasan, Iqbal. 2006. Analisis Data Penelitian dengan Statistik. Jakarta: Bumi Aksara.

Holmes. 2000. Gendered Speech in Social Context: Perspectives from Gown and Town. Wellington: Victoria University Press.

Pringgawidagda, Suwarna. 2002. Strategi Penguasaan Berbahasa.

Yogyakarta: Pustaka Pelajar

Ridwan Nawawi, Muhammad. 2008. Analisis Dan Perancangan Aplikasi Jejaring Sosial Penjualan Berbasis Web. Jakarta: Binus

Soeparno. 1993. Dasar-dasar Linguistik. Yogyakarta: Mitra Gama Widya

http://ejournal.unkhair.ac.id/index.php/humano 276 
Jurnal Penelitian Humano, Vol. 9 No. 2 Edisi November 2018

Sudjana. 2001. Prosedur Penelitian: Suatu

Pendekatan

Praktek.

Jakarta:Rineka Cipta.

Suyanto. Bagong. Sutinah. 2007. Metodologi Penelitian Sosial.
Tamburaka. Apriadi. 2013. Agenda Setting. Media Massa. Bandung: Remaja Rosdakarya.

Jakarta: Kencana. 